\title{
Specific Direction: An Unspecific Threshold
}

Dhruv Sharma*

DOI: $10.21827 / 5 b f 3 e a 247 \mathrm{dfc} 8$

\section{Keywords}

SPECIFIC DIRECTION; AIDING AND ABETTING; ICTY; PERISIC; INTERNATIONAL CRIMINAL COURT; ROME STATUTE; ARTICLE 25(3)(C); INDIVIDUAL CRIMINAL RESPONSIBILITY

\begin{abstract}
Aiding and abetting has been recognised as a form of individual criminal responsibility since the 1940's when the first international tribunals were created. The form of responsibility had a relatively simplistic history of application until it faced an unprecedented upheaval through the introduction of the threshold of specific direction in the Perišic appeals judgment. The judgment has since been rejected by the Special Court of Sierra Leone (SCSL) in the Charles Taylor judgment and by the International Criminal Tribunal for Former Yugoslavia (ICTY) in Sainovic, Popović and Stanišić and Simatović judgment.

The present paper focuses on the relevance of the standard of specific direction before the International Criminal Court (ICC). It argues that the standard is unjustifiable under international criminal law as, firstly, no convictions or acquittals have been affected on the standard and, secondly and more importantly, the text of the Rome Statute has rejected the standard. The standard of specific direction has not legal pedigree under customary law, is contrary to the text of the Rome Statute and counter-intuitive to the objectives of the ICC as it unreasonably increases evidentiary requirements at the Court and consequently makes the fight against impunity, an already challenging task, even more difficult.
\end{abstract}

\section{Introduction}

The International Criminal Court (ICC) was established with a multiplicity of objectives, foremost amongst which was and is to bring an end to impunity. ${ }^{1}$ Over the course of its short existence, the Court has faced a host of challenges to this objective, ranging from suspects evading arrest to non-cooperation by member States. Amongst these challenges facing the Court lies another potential challenge of threshold ${ }^{2}$ a challenge that raises the question: when does criminal responsibility ending impunity attach in the case of aiding and abetting?

The answer to this question remained relatively straightforward until February 2013. Any person who knowingly supported the principle perpetrator in the commission or attempted commission of international crimes where such support had a substantial effect

* LL.M. Candidate and Chevening Cambridge Trust Scholar at the University of Cambridge.

Rome Statute of the International Criminal Court (ICC), preamble.

The terms standard and threshold have been used synonymously. 
upon the commission was held to have committed aiding or abetting. ${ }^{3}$ However, the Appeals Chamber (AC) of the International Criminal Tribunal for Former Yugoslavia (ICTY), in Prosecutor $v$. Perišic ${ }^{4}$ significantly affected the seemingly settled law on aiding and abetting by curiously introducing (or re-introducing) another element, namely 'specific directions', for establishing the particular form of individual criminal responsibility. The element required the accused to not only substantially assist but also to specifically direct such assistance towards the aiding or abetting a crime. The judgment faced widespread criticism ${ }^{5}$ for the fear that it could cripple the fight against impunity. ${ }^{6}$

The precedent was subsequently weakened - first by the Special Court of Sierra Leone $(\mathrm{SCSL})^{7}$ and then by the ICTY itself. ${ }^{8}$ Today, while the standard remains constricted, the possibility of its application cannot be completely ruled out by merely relying on a body of persuasive precedents. ${ }^{9}$ Further, with the existence of alternate interpretations of aiding and abetting being laid down in Perišić and Charles Taylor and Sainovic and Stanišić and Simatović, the possibility of divergence in the jurisprudence on aiding and abetting under international criminal law cannot be ruled out. This divergence can fracture the consistency in jurisprudence and create fragmentation within a field that does not consist of binding precedents. $^{10}$

This article intends to discuss the requirement of specific direction with a particular focus on the ICC which is yet to lay down its own understanding of aiding and abetting. The present paper proceeds in the following manner. The first part traces the evolution and content of the specific direction threshold. The paper then turns to its core arguments that, firstly and more generally, the element of specific direction is not necessary for proving aiding and abetting under customary international criminal law. For this purpose, the author relies on the jurisprudence of the ICTY arguing that the Tribunal previously relied upon

International Criminal Tribunal for the Former Yugoslavia (ICTY), IT-95-17/1-T, Prosecutor v Furundzija, 10 December 1998, para 249.

4 ICTY, ICTY-IT-04--81-A, Prosecutor v Perisic, 28 February 2013.

5 Ventura, MJ, "Farewell 'Specific Direction': Aiding and Abetting War Crimes and Crimes Against Humanity in Perisić, Taylor, Sainović et al, and US Alien Tort Statute Jurisprudence", in Stuart, CM (ed.), The War Report: Armed Conflict in 2013, Geneva Academy of International Humanitarian Law and Human Rights, 511, 512-13 (May 1, 2014); Stewart, J, "Specific Direction" is Unprecedented: Results from Two Empirical Studies, EJIL:Talk! European Journal of International Law blog, 4 September 2013, at $<$ http://www.ejiltalk.org/specific-direction-is-unprecedented-results-from-two-empirical-studies/> (accessed 20 November 2018).

6 NY Times, Roth, K, A Tribunal's Legal Stumble, at <http://www.nytimes.com/2013/07/10/ opinion/global/a-tribunals-legal-stumble.html?_r=0>, (accessed 20 November 2018).

7 Special Court for Sierra Leone (SCSL), SCSL-03-01-A, Prosecutor v Charles Ghankay Taylor, 26 September $2013 \mathrm{http} / / /$ www.rscsl.org/Documents/Decisions/Taylor/Appeal/1389/SCSL-03-01-A-1389.pdf.

8 ICTY, Prosecutor $v$ Nikola Sainovic, IT-05-87-A, 23 January 2014, at <http://www.icty.org/x/cases/milutinovic/ acjug/en/140123.pdf> (accessed 20 November 2018); ICTY, Prosecutor v Popović et al, IT-05-88-A, 30 January 2015, Para 1758; ICTY, Prosecutor $v$ Stanišić and Simatović, IT-03-69-A, 9 December 2015, at <http://www.icty.org/x/cases/stanisic_simatovic/acjug/en/151209-judgement.pdf> (accessed 20 November 2018).

9 The International Criminal Court is not bound by its previous case law. Article 21 of the ICC Statute specifically allows for previous case law to be relied upon only as a subsidiary means for interpretation.

10 Carcano, A, "Of Fragmentation and Precedents in International Criminal Law: Possible Lessons from Recent Jurisprudence on Aiding and Abetting Liability", 14(4) Journal of International Criminal Justice, 771. 
certain elements to prove aiding and abetting, and that while the terminology 'specific direction' was not abandoned, it was not relied upon as well. Secondly, the paper would argue more specifically that the framework of the Rome Statute removed the requirement (if any) of the establishment of specific direction when it departed from the Statutes of the ICTY and SCSL. To carve out such deviation made by Assembly of State Parties, the author will delve into the interpretation of the provisions of the Rome Statute, as well as the standard of mental element set under the Statute. Finally, the paper shall conclude that any addition of the element of specific direction would be not only be contrary to the literal interpretation of the Statute but also counter-intuitive to the objective of the ICC as such a standard would excessively increase the evidentiary requirements at the ICC, consequently making the fight against impunity, an already challenging task, even more difficult.

\section{The Specific Direction Test}

The AC in Perišić, relying upon paragraph 229 of the Tadic Appeals judgment, ${ }^{11}$ reversed the decision of the Trial Chamber (TC), holding that in cases of remoteness of the accused from the scene of the crime, the prosecution had to additionally prove that the accused had specifically directed his assistance towards the commission of the crime. ${ }^{12}$ At the outset, it must be noted that the AC did not clarify the kind or type of directions requisite to aiding or abetting, merely observing that such analysis could only be case specific.

Before commenting on the interpretation relied upon by the $\mathrm{AC}$, it would be prudent to analyze the alleged source of the test, that is, the Tadic Appeals Judgment itself. The Tadic $\mathrm{AC}$ had then held that:

[t]he aider and abettor carries out acts specifically directed to assist, encourage or lend moral support to the perpetration of a certain specific crime (murder, extermination, rape, torture, wanton destruction of civilian property, etc.), and this support has a substantial effect upon the perpetration of the crime. ${ }^{13}$

The AC in Tadic provided the aforementioned understanding of aiding and abetting to differentiate this form of individual criminal responsibility from joint criminal enterprise. ${ }^{14}$ The main objective of the formulation was thus to illustrate that while in the case of joint criminal enterprise a common concerted plan was necessary, aiding and abetting required practical assistance by the accused to the principle perpetrator. ${ }^{15}$

The loose terminology used by the $\mathrm{AC}$ was subsequently reproduced in several cases, such as Blaškic ${ }^{16}{ }^{\text {Vasiljević, }}{ }^{17}$ Krnojelac, $^{18}$ and Kupreškić, ${ }^{19}$ which led to its further literal entrenchment into the ICTY case law.

11 ICTY, The Prosecutor $v$ Tadic, IT-94-1-A, 15 July 1999, para 229 (emphasis added).

12 ICTY, Prosecutor $v$ Perisic, 28 February 2013, ICTY-IT-04--81-A, para 38.

13 ICTY, The Prosecutor $v$ Tadic, IT-94-1-A, 15 July 1999, para 229 (emphasis added).

14 Trahan, J, Lovall, EK, "The ICTY Appellate Chamber's Acquittal of Momcilo Perisic: The Specific Direction Element of Aiding and Abetting Should Be Rejected or Modified to Explicitly Include a 'Reasonable Person' Due Diligence Standard”, Brook. Journal of International Law (2014) 172, p. 203.

15 Shaw, D, "Prosecutor v Taylor: Is the SCSL's Rejection of the Specific Direction Enigma Enough to End Debate Between the Ad Hoc Tribunals?", 22 Tul. J. Int'l \& Comp. L. (2013-2014) 425, p. 431; ICTY, The Prosecutorv Tadic, IT-94-1-A, 15 July 1999, paras 228-229.

16 ICTY, Prosecutor v Blaškić, IT-95-14-A, 29 July 2004, para 45, at <http://www.icty.org/x/cases/blaskic/ acjug/en/bla-aj040729e.pdf> (accessed 20 November 2018). 
In 2011, the TC, while convicting Perisic for aiding and abetting the crimes perpetrated by the Vojska Republike Srpske (VRS), concluded that Perisic had presided over a system that provided comprehensive military assistance to the VRS. The TC was consequently of the opinion that in the absence of an assistance by Perisic, the VRS would not have been able to implement its war strategy which included systematic commission of crimes. ${ }^{20}$ The TC then specifically went on to hold that the absence of any express instructions to commit crimes did not absolve Perisic, as a causal relationship between the assistance and the crimes or a specific direction towards the commission of the crimes was not a sine qua non under aiding and abetting. ${ }^{21}$ The TC therefore went on to find that the assistance provided by Perisic substantially contributed towards the crimes ultimately committed by the VRS during the Siege of Sarajevo and in Srebrenica. ${ }^{22}$

The AC in its part did not rebut the findings of the TC that Perisic knew, at the time of assisting the VRS, of the crimes being perpetrated by the organisation. However, it held that in addition to the knowledge of the crimes being perpetrated by VRS, Perisic should have specifically directed his assistance towards those crimes. The AC, therefore, not only relied on an element whose inception itself was misleading but also conflated knowledge an indicator of mens rea - with specific directions, understood by the Court itself as an element of actus reus, ${ }^{23}$ when it held that knowledge could serve as circumstantial evidence of specific direction but could not conclusively manifest the same. ${ }^{24}$ The Court then overruled the findings of the TC and held that in the absence of any cogent reasons to depart from established law, the TC had erred in sidestepping the requirement of specific direction. Thus, the AC, sourcing the legal pedigree of specific direction under customary international law through the constant reiteration of the Tadic formulation in subsequent ICTY case law, firmly established the requirement of specific direction under the head of aiding and abetting. The AC consequently acquitted Perisic on all counts. ${ }^{25}$

The acquittal of Perisic was received by the international criminal law community with shock and an apprehension that the decision would be a blow to the gradual but unprecedented move against impunity. ${ }^{26}$ Allegations of larger political implications

17 ICTY, Prosecutor v Vasiljević, IT-98-32-A, 25 February 2004, para 102, at <http://www.icty.org/x/cases/ vasiljevic/acjug/en/val-aj040225e.pdf> (accessed 20 November 2018).

18 ICTY, Prosecutor $v$ Krnojelac, IT-97-25-A, 17 September 2003, para 33, at <http://www.icty.org/x/ cases/krnojelac/acjug/en/krn-aj030917e.pdf> (accessed 20 November 2018).

19 ICTY, Prosecutor v Kupreškić et al, IT-95-16-A, 23 October 2001, para 254, at <http://www.icty.org/x/ cases/kupreskic/acjug/en/kup-aj011023e.pdf> (accessed 20 November 2018).

20 ICTY, Prosecutor v Perisic, IT-04-81-T, 6 September 2011, paras 1621-1627.

21 Ibid., para 1624.

22 Ibid., paras 1621-1627; ICTY, IT-04-81-A, Prosecutor v Momcilo Perisic, Partially Dissenting Opinion of Judge Liu, 28 February 2013, paras 4-7.

23 ICTY, ICTY-IT-04--81-A, Prosecutor $v$ Perisic, 28 February 2013, paras 25 and 33 , at $<$ http://www.icty.org/x/cases/perisic/acjug/en/130228_judgement.pdf> (accessed 20 November 2018).

24 Ibid., paras 68.

25 Ibid., paras 74 and 122.

26 Aksenove, M, "The Specific Direction Requirement for Aiding and Abetting: A Call for Revisiting Comparative Criminal Law", 4 Cambridge J. Int'l \& Comp. L. 88 (2015), 107; Coco, A and Gal, T, "Losing Direction: The ICTY Appeals Chamber's Controversial Approach to Aiding and Abetting in Perišić", 12 Journal of International Criminal Justice (2014) 345, pp. 365-366; NY Times, Roth, K, A Tribunal's Legal 
influencing the ICTY flew around. ${ }^{27}$ Authors argued that State concerns regarding provisioning of assistance to other countries being affected by a lower standard under aiding and abetting led to the abrupt increase in the threshold. ${ }^{28}$

\section{Evaluation of the Specific Direction Doctrine}

Despite stringent criticism of the doctrine by several scholars, ${ }^{29}$ the judgment did find some support. ${ }^{30}$ It would therefore be prudent to analyze the arguments put forth in defense of specific direction before embarking upon an evaluation of the same.

\section{A. Justification for Specific Direction}

The strongest and perhaps the only argument put forth in favour of specific direction is the practicality of aiding and abetting in the absence of such a requirement. ${ }^{31}$ The argument brought forth by the affirming scholars is best explained through an illustration:

Country A provides arms and ammunitions to the armed forces of Country B which are engaged in an armed conflict with a belligerent group within their border. These munitions are utilized for lawful as well as unlawful purposes. Country A has knowledge that certain part of their support is being utilized to commit international crimes. Should the chief of army of Country A be responsible under aiding and abetting for provisioning munitions to the armed forces of B despite such knowledge? ${ }^{32}$

Judge Meron, President of the ICTY, was of the view that such support cannot attract criminal responsibility under aiding and abetting as the organisation to which arms are being

Stumble, at <https://www.nytimes.com/2013/07/10/opinion/global/a-tribunals-legal-stumble.html> (accessed 20 November 2018).

27 Opinio Juris, Heller, KJ, The Real Judge Meron Scandal at the ICTY, at <http://opiniojuris.org/2013/06/17/thereal-judge-meron-scandal-at-the-icty/> (accessed 20 November 2018); Wikileaks, ICTY: President Meron Urges USG To Oppose Del Ponte Renewal, at <https://www.wikileaks.org/plusd/cables/03THE HAGUE1827_a.html> (accessed 09 January 2019).

28 The New York Times, Marlise Simons, M, Judge at War Crimes Tribunal Faults Acquittals of Serb and Croat Commanders, 14 June 2013, at <http://www.nytimes.com/2013/06/15/world/europe/judge-at-war-crimestribunal-faults-acquittals-of-serb-and-croat-commanders.html?_r=0Marko Milanovic > (accessed 20 November 2018); EJIL:Talk!, Milanovic, M, Danish Judge Blasts ICTY President [UPDATED], 13 June 2013, at <http://www.ejiltalk.org/danish-judge-blasts-icty-president/> (accessed 20 November 2018).

29 Trahan, Lovall, supra nt 14, 184.

30 Opinio Juris, Heller, KJ, The SCSL's Incoherent - and Selective - Analysis of Custom, 27 September 2013, at $<$ http://opiniojuris.org/2013/09/27/scsls-incoherent-selective-analysis-custom/> (accessed 20 November 2018).

31 ICTY, Prosecutor v Perisic, IT-04-81-T, 6 September 2011, Dissenting Opinion Of Judge Moloto on Counts 1 To 4 And 9 To 12, paras 32-33, at <http://www.icty.org/x/cases/perisic/tjug/en/110906_judgement.pdf $>$ (accessed 20 November 2018); ICTY, Prosecutor v Perisic, IT-04-81-A, Transcript of Appeals Chamber Hearing: 30 October 2012, p. 62; Opinio Juris, Heller, KJ, Why the ICTY's 'Specifically Directed' Requirement Is Justified, 2 June 2013, at <http://opiniojuris.org/2013/06/02/why-the-ictys-specifically-directed32 requirement-is-justified/> (accessed 20 November 2018).

2 Ibid. 
provided is engaged in both lawful and unlawful activities. ${ }^{33}$ This opinion is also echoed by Professor Kevin Heller who has previously articulated his support for specific directions as an element under aiding and abetting until the mens rea standard for the form of criminal responsibility is increased from mere knowledge. ${ }^{34}$

While the very legal basis of specific direction remains questionable, it is imperative to ask a more fundamental question: why not? Why shouldn't a military leader who continues to support an armed group, despite knowledge of the committal of international crimes and violations of international humanitarian law (IHL), be held responsible for aiding and abetting such crimes? The rules under the Hague Regulations, the Geneva Conventions and its additional Protocols, and under the customary international criminal law do not consider a combination of lawful and unlawful activities as a valid justification to deviate from such Regulations. Therefore, the exposition by the ICTY, which had to apply such rules while arriving at its decisions, cannot unilaterally create such an exception to responsibility.

As a principle, the laws of armed conflict developed, amongst other reasons, due to the unfortunate inevitability of war. ${ }^{35}$ The laws aimed at maintaining the basic minimum level of humanity even during an otherwise inhumane activity, such as a war. To now argue that an individual should overlook (and thereby condone) the violations of this minimum standard set by the laws of war merely because they go alongside lawful combat activities is betraying the very foundations of IHL. ${ }^{36}$ While the degree of mens rea required to evidence an individual's complicity may be argued upon, the actus reus, so long as the support considerably contributes towards the crimes, cannot be heightened to such an extent as to make the laws of war otiose. The principles of criminal law must be developed on a morally defensible basis, ${ }^{37}$ and the fact that the attachment of responsibility may have certain geopolitical implications cannot be a factor.

\section{B. The Fallibility of Specific Directions}

Specific direction, despite being introduced as far back as in 1998 and having been reiterated in subsequent case laws, was never identified as a separate element of aiding and abetting. ${ }^{38}$ Two reasons may be identified for such a situation. Firstly, the observations of the AC in Tadic qualified merely as obiter dictum. ${ }^{39}$ As was mentioned in Section II, Tadic merely used

33 ICTY, Prosecutor v Perisic, IT-04-81-A, Transcript of Appeals Chamber Hearing: 30 October 2012, p.62.

34 Heller, supra nt 31; Opinio Juris, Heller, KJ, My Talk in London Defending the Specific-Direction Requirement, 26 October 2013, at <http://opiniojuris.org/2013/10/26/talk-london-defending-specific-directionrequirement/> (accessed 20 November 2018). The author provides a link summarising his views on the issue in the aforementioned link.

35 Kalshoven, F, and Zegveld, L, "Constraints On The Waging Of War An Introduction To International Humanitarian Law", (ICRC Geneva), p. 12 -15, at <https://www.loc.gov/rr/frd/Military_Law/pdf/ Constraints-waging-war.pdf $>$ (accessed 20 November 2018).

36 Ibid.

37 Stuart, CM, "Specific Direction" is Indefensible: A Response to Heller on Complicity, 12 June 2013, at $<$ http://opiniojuris.org/2013/06/12/specific-direction-is-indefensible-a-response-to-heller-on-complicity/> (accessed 20 November 2018).

38 ICTY, Prosecutor v Momcilo Perisic, IT-04-81-A, Partially Dissenting Opinion of Judge Liu, 28 February 2013, paras 3; Shaw, supra nt 15, p. 431.

39 Coco and Gal, supra nt 26, pp. 354-55. 
the term '...specifically directed' to differentiate joint criminal enterprise from aiding and abetting. The Court was adjudicating upon aiding and abetting as a form of criminal responsibility. Therefore, the observations did not establish any precedent to which subsequent chambers must give deference in the absence of any cogent reasons for deviation. ${ }^{40}$ Moreover, the customary nature of specific direction as introduced by the Tadic Appeals is itself questionable. ${ }^{41}$ The AC, in developing this terminology, did not rely on any precedent or international instrument evident from the absence of reliance on any authority to establish the customary status of specific direction..$^{42}$ Secondly, the incorporation of the terminology by subsequent judgments was rather mechanical in nature, with none of the cases explaining the meaning, the scope or in the very least its application to the case. ${ }^{43}$ Specific direction was not identified as an element of aiding and abetting prior to Tadic, and even afterwards, while several judgments mention it, it is doubtful whether any acquittal was effected (except Perisic) in its absence. ${ }^{44}$ The AC unfortunately traced down specific direction to have a customary nature while nothing in case law, or academic writings manifests the same, and the repeated iteration of an assertion does not convert it into law. ${ }^{45}$

In contrast with the observation of the AC in Tadic, a comprehensive study into the law of aiding and abetting had already been done by the ICTY in Anto Furundžija, wherein it examined several post World War II judgments to identify the elements encompassing aiding and abetting. ${ }^{46}$ The TC therein held that, under customary international criminal law, the actus reus of aiding and abetting required practical assistance on part of the aider or abettor of the principle perpetrator which had a substantial effect on the commission of the crime. ${ }^{47}$ Practical assistance could be in the form of moral support or encouragement of the principal perpetrator, even if the same did not have any causal relationship with the final act. ${ }^{48}$ The TC also explicitly discounted the possibility of the actus reus requiring any direct assistance stating that that such a terminology was misleading as it implied the requirement of a tangible form of assistance, while the same was not a requisite as understood by erstwhile Tribunals, as well as Member States during the negotiations on the Rome Statute. ${ }^{49}$

The findings of the TC in Furundžija were subsequently upheld by the $\mathrm{AC}^{50}$ a year after the Tadic Appeals judgment, indicating that the dual elements forming an essential part of the actus reus of aiding and abetting liability are: a) assistance, moral support or

40 Ventura, supra nt 5; Stuart, supra nt 5, 511, 522.

41 ICTY, Prosecutor v Nikola Sainovic, IT-05-87-A, 23 January 2014, para 1650, at <http://www.icty.org/x/ cases/milutinovic/acjug/en/140123.pdf $>$ (accessed 20 November 2018); Aksenove, supra nt 26, 92-94.

42 Ventura, supra nt 5, p. 11; ICTY, The Prosecutor $v$ Tadic, IT-94-1-A, 15 July 1999, para 229. Note the conspicuous absence of any footnotes to the proposition laid down by the AC.

43 Shaw, supra nt 15, 431; Trahan, Lovall, supra nt 14, 184.

44 Stewart, supra nt 5.

45 Ventura, supra nt 5, 11.

46 ICTY, Prosecutor v Furundzija, IT-95-17/1-T, 10 December 1998, at <http://www.icty.org/x/cases/furundzija/ tjug/en/fur-tj981210e.pdf> (accessed 20 November 2018).

$47 \quad$ Ibid., para 235.

48 Ibid., para 233.

49 Ibid., paras 231-232.

50 ICTY, Prosecutor v Furundzija, IT-95-17/1-A, 21 July 2000, at <http:/www.icty.org/x/cases/furundzija/ acjug/en/fur-aj000721e.pdf> (accessed 20 November 2018). 
encouragement, b) which had a substantial effect on the commission of the crime. ${ }^{51}$ Unlike the terminology employed in Tadic, the two elements recognised by TC and later affirmed by AC in Furundžija have been actively cited and used to effect convictions or acquittals at the Court. For instance, in Aleksovski, the AC cited paragraph 229 of Tadic AC judgment ${ }^{52}$ but based the conviction of the accused on the twin criteria laid down in Furundžija, i.e. for his encouragement that had a substantial effect on the mistreatment of the HVO soldiers by the perpetrators. ${ }^{53}$ Similarly in Brdanin, the AC acquitted the accused on the count of committing torture by holding that the Prosecution had failed to prove that the acts of Brdanin amounted to an encouragement that could have a substantial effect on the commission of the crime. ${ }^{54}$ The AC therefore quite conspicuously circumvented the requirement of specific directions. Finally, in Kupreskic, a case cited by the AC in Perisic, the acquittal of the accused was in effect not done because of the absence of specific directions but due to circumstantial evidence failing to prove that his acts had a substantial effect on the commission of the crime. ${ }^{55}$

In fact, several cases at the ICTY explicitly rejected the requirement of specific direction on the ground that it was not an element of aiding and abetting liability. In Mrkšić et al., the AC, relying upon Blagojević and Jokić, held that specific direction was not an essential element of aiding and abetting. ${ }^{56}$ In Perisic, the AC held that the Court in Mrkšić had failed to give cogent reasons for their deviation from an already settled law on aiding and abetting and therefore had erred in diluting specific directions. ${ }^{57}$ However, as has been stated earlier, the legal pedigree of specific direction is dubious in the very least and the findings of the Court in Mrkšic in fact make explicit the futility of the specific direction test. Further, considering that the inception of specific direction was itself in the form of an obiter dictum and not ratio decidendi, it was not incumbent upon AC in Mrkšić to cite reasons for their departure. It is for the same reason that the ICTY, in Sainovic - a more recent judgment on aiding and abetting -went on to explicitly hold that the terminology coined by AC in Tadic did not form a precedent for subsequent Courts to follow. ${ }^{58}$ Even the SCSL, upon receiving the argument on specific direction from Charles Taylor, held that the same did not form a part of customary law on aiding and abetting, and that the ICTY had in fact erred in so far as it had sought to understand specific direction as a prerequisite for proving aiding and

51 Ibid., paras 124-127.

52 ICTY, Prosecutor $v$ Zlatko Aleksovski, IT-95-14/1-A, 24 March 2000, para 163, at $<$ http://www.icty.org/x/cases/aleksovski/acjug/en/ale-asj000324e.pdf $>$ (accessed 20 November 2018).

53 Ibid., para 172.

54 ICTY, Prosecutor $v$ Radoslav Brđanin, IT-99-36-A, 3 April 2007, paras 276-277, 288-89, at $<$ http://www.refworld.org/docid/48aae70a2.html> (accessed 20 November 2018).

55 ICTY, Prosecutor v Zoran Kupreškić Mirjan Kupreškić Vlatko Kupreškić Drago Josipoviić Vladimir Šantic, IT-9516-A, 23 October 2001, 292-296, 303-304, at <http:/www.icty.org/x/cases/kupreskic/acjug/en/kupaj011023e.pdf $>$ (accessed 20 November 2018).

56 ICTY, Prosecutor v. Mile Mrkšić and Veselin Śljivančanin, IT-95-13/1-A, 5 May 2009, para 159; IT-02-60-A, Prosecutorv Vidoje Blagojević and Dragan Jokić, 9 May 2007, para 189.

57 ICTY, Prosecutor v Perisic, ICTY-IT-04--81-A, 28 February 2013, paras 32-35.

58 ICTY, Prosectuor v Nikola Sainovic, IT-05-87-A, 23 January 2014, para 1623, 1626-1650. 
abetting..$^{59}$ Finally, the ICTY has gone on to observe that the doctrine of specific direction was recognised neither in the jurisprudence of the Tribunal nor under customary international law. ${ }^{60}$

Additionally, the dual requirement of specific directions and substantial effect is highly problematic. Principally, if substantial effect is established (along with knowledge of the commission), then it must necessarily imbibe acknowledgment of the crime and directives to commit the crime in the sense that the encouragement would be assisting the commission of the crime. The inclusion of specific direction adds a level of impracticality to the theory of aiding and abetting as the necessary implications flowing from the theory would then be that if directives include lawful and unlawful activities, then the crime would never be committed. The AC, in fact, made a similar observation when it proposed that general assistance, which could be useful for both lawful and unlawful purposes, is not sufficient for aiding and abetting. ${ }^{61}$ Quite obviously, if the assistance provided was for lawful purposes and the perpetrator singularly carried out crimes without the knowledge of the accused or without the accused substantially assisting the crime, the accused may not be guilty for aiding and abetting. However, in situations where in spite of the knowledge of the crimes the accused still directs his assistance even for legitimate purposes, the knowledge combined with the effect of the assistance on the crime should suffice conviction.

The idea that an accused, who is proved to have substantially aided organisations responsible for international crimes, should walk free on an extremely thin rope under positive international criminal law lacks any legal or even moral conviction.

\section{Aiding and Abetting at the International Criminal Court}

The flight of specific direction from Tadic to Sainovic to Popović, and thereafter Stanisic and Simatovic, attains greater importance due to the potential effect it can have on the ICC, which in its nascent years has relied heavily on the jurisprudence of the ICTY. ${ }^{62}$ This reliance, especially on interpretation of substantive law such as that of aiding and abetting, despite the differential structuring of the ICC and other ad-hoc international tribunals, is essential to avoid fragmentation and strive towards the ideal of universality of international criminal law. ${ }^{63}$

The ICC has not yet dealt concretely with the law on aiding and abetting, with only the Pre-Trial Chamber (PTC) making observations regarding the same.$^{64}$ In the few cases concerning aiding and abetting that have come before the Court, the approach of the PTC

59 SCSL, Prosecutor $v$ Charles Ghankay Taylor, SCSL-03-01-A, 26 September 2013, paras 481-486, at $<$ http://www.rscsl.org/Documents/Decisions/Taylor/Appeal/1389/SCSL-03-01-A-1389.pdf $>\quad$ (accessed 20 November 2018).

60 ICTY, Prosecutor $v$ Stanišić and Simatović, IT-03-69-A, 9 December 2015, para 104-106, at $<\mathrm{http} / / / \mathrm{www}$. icty.org/x/cases/stanisic_simatovic/acjug/en/151209-judgement.pdf $>$ (accessed 20 November 2018); IT-05-88-A, Prosecutor v Popović et al, 30 January 2015, Para 1758.

61 ICTY, Prosecutor v Perisic, ICTY-IT-04--81-A, 28 February 2013, para 44.

62 Viebig, P, Illicitly Obtained Evidence at the International Criminal Court, (International Criminal Justice Series 4, Asser Press), 27-28; International Criminal Court (ICC), Prosecutor v Thomas Lubanga Dyilo, ICC-01/0401/06, Judgment pursuant to Article 74 of the Statute, paras 533-536 and 603.

63 Viebig, supra nt 62, 24.

64 ICC, The Prosecutor v Callixte Mbarushimana, ICC-01/04-01/10; ICC, The Prosecutor v. William Samoei Ruto and Joshua Arap Sang, ICC-01/09-01/11. 
has been diametrically opposite with the Chamber favouring the substantial effect doctrine of the ICTY in two cases ${ }^{65}$ and explicitly rejecting the same (without providing any alternative) in another. ${ }^{6}$ The latter approach may owe its origin to the fact that Article 25(3)(c) of the Rome Statute provides for any sort of assistance to be culpable for aiding and abetting, in contrast with the settled stand of the ad-hoc tribunals that the assistance should be substantial. ${ }^{67}$ The non-inclusion of the 'directly and substantially' requirement for aiding and abetting from Article 2(3)(d) of the Draft Code of Crimes adds further to the belief that substantial assistance may not have been decided upon as a standard at the ICC. However, the absence of such terminology, in fact, reflects an adherence to the Statutes of the ICTY, ICTR or the SCSL, which also did not include an explicit requirement of substantial assistance, ${ }^{68}$ and such a requirement was sourced through customary international law which identified assistance to subsume and imply substantial assistance for attachment of culpability. ${ }^{69}$ Therefore, it is unlikely that the ICC would go forward with merely any form of assistance to establish responsibility under aiding and abetting.

An arguably more important issue concerns the level of mens rea required to attract culpability under aiding and abetting. The Ad Hoc Tribunals, as well as scholars, have previously been of the unanimous opinion that the mens rea for aiding and abetting is knowledge. However, the language of Article 25(3)(c) states:

... For the purpose of facilitating the commission of such a crime, aids, abets or otherwise assists in its commission or its attempted commission, including providing the means for its commission;

The Statute thus requires that the assistance be provided for the purpose of facilitating the commission or attempted commission of the crime. This purpose requirement, despite not having yet been adjudicated upon by the ICC, has already made scholars anxious as to its scope and consequential effect. ${ }^{70}$

The purpose requirement under Article 25(3)(c) is a novelty brought into the Rome Statute from the Model Penal Code of the American Law Institute. ${ }^{71}$ Relying upon the

65 ICC, The Prosecutor v. Callixte Mbarushimana, ICC-01/04-01/10, para 279; ICC, The Prosecutor v William Samoei Ruto and Joshua Arap Sang, ICC-01/09-01/11, para 354.

66 ICC, The Prosecutor v. Blé Goudé, Confirmation of Charges Decision, ICC-02/11-02/11-186, para 167.

67 ICTY, Prosecutor v Furundzija, IT-95-17/1-T, 10 December 1998; SCSL, Prosecutor $v$ Charles Ghankay Taylor, SCSL-03-01-A, 26 September 2013, para 391, at <http://www.rscsl.org/Documents/Decisions/Taylor/ Appeal/1389/SCSL-03-01-A-1389.pdf> (accessed 20 November 2018).

68 Article 7(1) ICTY Statute; Article 6(1) ICTR Statute; Article 6(1) SCSL Statute; William Schabas, $A n$ Introduction to International Criminal Court (4th ed. Cambridge University Press 2011), 228.

69 ICTY, Prosecutor v Furundzija, IT-95-17/1-T, 10 December 1998; SCSL, Prosecutor v Charles Ghankay Taylor, SCSL-03-01-A, 26 September 2013, para 391.

70 Ibid.; Scheffer, DJ, "Brief of David J. Scheffer, Director of the Centre of International Human Rights, as Amicus Curiae in Support of the Issuance of a Writ of Certiorari", in Presbyterian Church of Sudan v Talisman Energy Inc. before the Supreme Court of United States, 19 May 2010; James G. Stewart Blog, Van Sliedregt, E and Popova, A, Interpreting "For the Purpose of Facilitating" in Article 25(3)(C)?, 22 December 2014, at $<$ http://jamesgstewart.com/interpreting-for-the-purpose-of-facilitating-in-article-253c/> (accessed 20 November 2018).

71 Ambos, K, "General principles of criminal law in the Rome Statute", 10 Criminal Law Forum (1999) 1, 10. 
model code itself, interpretation of the requirement has ranged from arguments in favour of an intent requirement ${ }^{72}$ to arguments equating purpose to knowledge itself. ${ }^{73}$

The author is of the view that the purpose requirement in fact compliments the mens rea standard provided for under Article 30. Article 30 of the Statute provides for the mental element for crimes unless otherwise provided for in the Statute. Barring crimes such as genocide, persecution, or torture ${ }^{74}$ that require an increased form of mental element, crimes under the Statute base their mens rea requirement on Article 30. Article 30 separately defines intent for conduct and consequences. ${ }^{75}$

The TC of the ICC in Bemba et al. while dealing with Article 25(3)(c) held that the mens rea under aiding and abetting may be divided into two parts; one relating to the conduct of the aider and abettor i.e. the accused and the other relating to the conduct of the principal perpetrator. ${ }^{76}$ The Bemba TC then clarified that the purpose requirement only relates to the former, i.e. the facilitation of the crime and not the principal offence, for which Article 30 continued to remain applicable. ${ }^{77}$ It is pertinent to note that the Appeals Chamber despite overturning TC judgment did not in fact overrule the findings of the TC on this point.

The purpose requirement consequently attaches itself to the facilitation of assistance provided by the aider or abettor. Therefore, the accused should be aware that the offence by the principal perpetrator shall occur in the ordinary course of events ${ }^{78}$ akin to the erstwhile position of law before other international tribunals: $;^{79}$ however he/she must also purposefully facilitate the crime, that is to say, that the accused must facilitate the crime through a willful assistance ${ }^{80}$ and not assistance through negligence or recklessness. ${ }^{81}$ This characterisation of the purpose requirement relating to the conduct of the aider/abettor rather than to the crime committed by the principal perpetrator finds support in the Taylor Judgment as well. The AC, while considering the Ministries Trial, ${ }^{82}$ observed that the knowledge of the accused was

72 Reggio, A, "Aiding and Abetting In International Criminal Law: The Responsibility of Corporate Agents And Businessmen For 'Trading With The Enemy' of Mankind”, 5 International Criminal Law Review (2005) 623, p. 645.

73 Scheffer, DJ, "Brief of David J. Scheffer, Director of the Centre of International Human Rights, as Amicus Curiae in Support of the Issuance of a Writ of Certiorari", in Presbyterian Church of Sudan v Talisman Energy Inc. before the Supreme Court of United States, 19 May 2010.

74 Article 6 ICC Statute; Article 7(1)(h) read with Article 7(2)(g) ICC Statute; Article 7(1)(f) read with Article 7 (2)(e) ICC Statute.

75 Article 30(2)(a) and Article 30(2)(b) ICC Statute.

76 ICC, The Prosecutor v. Jean-Pierre Bemba Gombo, Aimé Kilolo Musamba, Jean-Jacques Mangenda Kabongo, Fidèle Babala Wandu and Narcisse Arido, ICC-01/05-01/13, para 97.

77 Ibid.

78 Article 30(2) ICC Statute.

79 Ventura, MJ, "Aiding and Abetting" in Jérôme de Hemptinne et al. (eds), Modes of Liability in International Criminal Law (Cambridge, Cambridge University Press 2019) (forthcoming), 55.

80 Eser, A "Individual Criminal Responsibility" in Cassese, A, et al (eds), The Rome Statute of The International Criminal Court: A Commentary (Oxford University Press 2002) p. 801; Schabas, supra nt 68.

81 James G. Stewart Blog, Stewart, J, An Important New Orthodoxy on Complicity in the ICC Statute?, 21 January 2015, at <http://jamesgstewart.com/the-important-new-orthodoxy-on-complicity-in-the-icc-statute/> (accessed 20 November 2018).

82 USA v Weizsäcker et al ('The Ministries Trial'). 
sufficient to fulfill the indicia of mens rea for aiding and abetting. ${ }^{83}$ The Appeals Chamber then went on to discuss that Karl Rasche, who had advanced the loans to the Nazi Schutzstaffel (SS), was not acquitted for the lack of mens rea in relation to the awareness of the crime which was clearly fulfilled through his knowledge but rather because he did not advance the loans with purpose that the borrower would use the funds to commit the crimes. ${ }^{84}$

In sum, the author acknowledges an increase in the threshold of aiding and abetting at the ICC in comparison to the ad hoc Tribunals; however, such increase is not through the inclusion of specific direction within the actus reus of the crime but through the inclusion of purpose requirement for the facilitation of assistance.

\section{Conclusion}

International criminal law has been entrusted with a responsibility to balance the rights of the accused with the fight against impunity. This balance has been maintained (more or less) by Ad-Hoc Tribunals quite remarkably. However, a few cracks have been noticed recently through the inclusion of unrealistic thresholds in proving culpability. One such challenge the requirement of specific directions within the actus reus of aiding and abetting. The inclusion of specific direction meant that the prosecution needed to not only show that an accused facilitated the commission of a crime by providing substantial assistance to the perpetrator but also that such assistance was specifically directed towards the crime. In this era, with decentralised and distant command structures and increasingly common geographically detached drone warfare, the requirement of specific direction, in fact, transports us back to a time where impunity could thrive due to the ineffectiveness of the law. It provides various important actors with the opportunity of avoiding culpability by arguing their absence from the scene of the crime or, worse yet, due to the absence of specific instructions to commit the crime. The reversal of the Perisic judgment by the SCSL and then the ICTY was the hopefully the final word on the issue. However, the requirement may be revisited by a future Court and thus it is prudent to highlight the logical and legal fallacies in the doctrine, so that future tribunals, as well as drafters, can make an informed decision with respect to the inclusion of such standards.

It is important to note that under customary international law actus reus of aiding and abetting requires only two factors: (i) practical assistance by the accused (ii) which had a substantial effect on the commission of the crime. This requirement remains true even for the ICC, which has, in terms of its language for actus reus, borrowed from the Ad Hoc Tribunals. However, with regards to the mens rea, while the customary requirement remains that of knowledge, the ICC incorporates a purpose requirement, in addition to the existing knowledge requirement, that necessitates that the assistance be provided with the purpose of facilitating the perpetrator.

83 SCSL, Prosecutor $v$ Charles Ghankay Taylor, SCSL-03-01-A, 26 September 2013, para 424, at <http://www.rscsl.org/Documents/Decisions/Taylor/Appeal/1389/SCSL-03-01-A-1389.pdf> (accessed 20 November 2018).

84 SCSL, Prosecutor $v$ Charles Ghankay Taylor, SCSL-03-01-A, 26 September 2013, n 1325, at <http://www.rscsl.org/Documents/Decisions/Taylor/Appeal/1389/SCSL-03-01-A-1389.pdf＞（accessed 20 November 2018). 
332 GroJIL 6(2) (2018), 320-332

The ICC augurs in a new era of international criminal justice. It is imperative for the Court to stay true to its mandate and continue its fight against institutionalised impunity.

www.grojil.org 